\title{
Vaginal Squamous Cell Papilloma
}

National Cancer Institute

\section{Source}

National Cancer Institute. Vaginal Squamous Cell Papilloma. NCI Thesaurus. Code C6374.

A benign papillary neoplasm that arises from the vagina and is characterized by the presence of a fibrovascular stalk lined by normal squamous epithelium. There is no evidence of atypia or relation to human papillomavirus. 